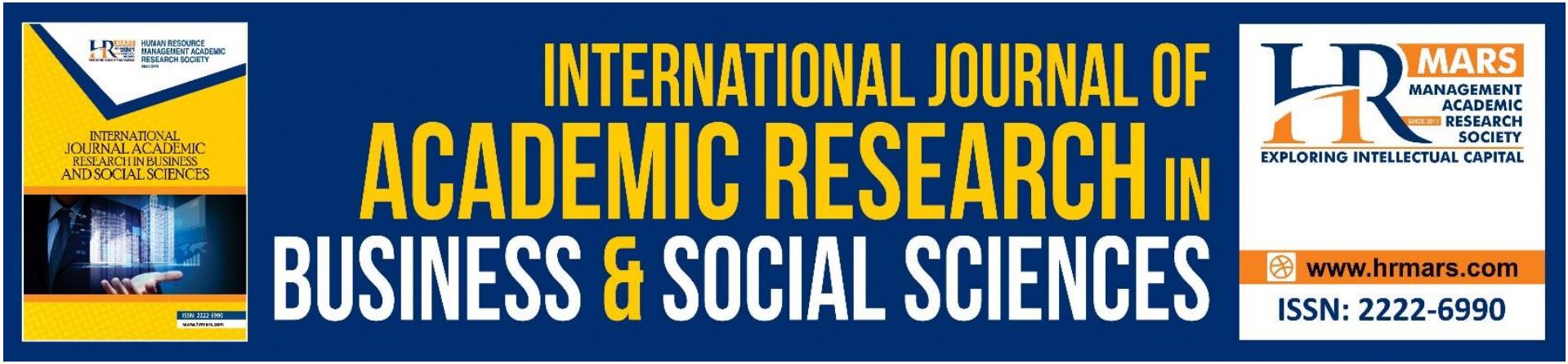

\title{
TVET Graduate Employability: Mismatching Traits Between Supply and Demand
}

Jeffridzal Bin Ismail, Chemah Tamby Chik, Mohammad Abdullah Hemdi

To Link this Article: http://dx.doi.org/10.6007/IJARBSS/v11-i13/8522

DOI:10.6007/IJARBSS/v11-i13/8522

Received: 18 November 2020, Revised: 13 December 2020, Accepted: 31 December 2020

Published Online: 25 January 2021

In-Text Citation: (Ismail et al., 2021)

To Cite this Article: Ismail, J. Bin, Chik, C. T., \& Hemdi, M. A. (2021). TVET Graduate Employability: Mismatching Traits Between Supply and Demand. International Journal of Academic Research in Business and Social Sciences, 11(13), 223-243.

Copyright: (c) 2021 The Author(s)

Published by Human Resource Management Academic Research Society (www.hrmars.com)

This article is published under the Creative Commons Attribution (CC BY 4.0) license. Anyone may reproduce, distribute, translate and create derivative works of this article (for both commercial and non-commercial purposes), subject to full attribution to the original publication and authors. The full terms of this license may be seen at: http://creativecommons.org/licences/by/4.0/legalcode

Special Issue: Beyond 2021 and COVID-19 - New Perspective in the Hospitality \& Tourism Industry, 2021, Pg. 223 - 243 http://hrmars.com/index.php/pages/detail/IJARBSS JOURNAL HOMEPAGE

Full Terms \& Conditions of access and use can be found at http://hrmars.com/index.php/pages/detail/publication-ethics 


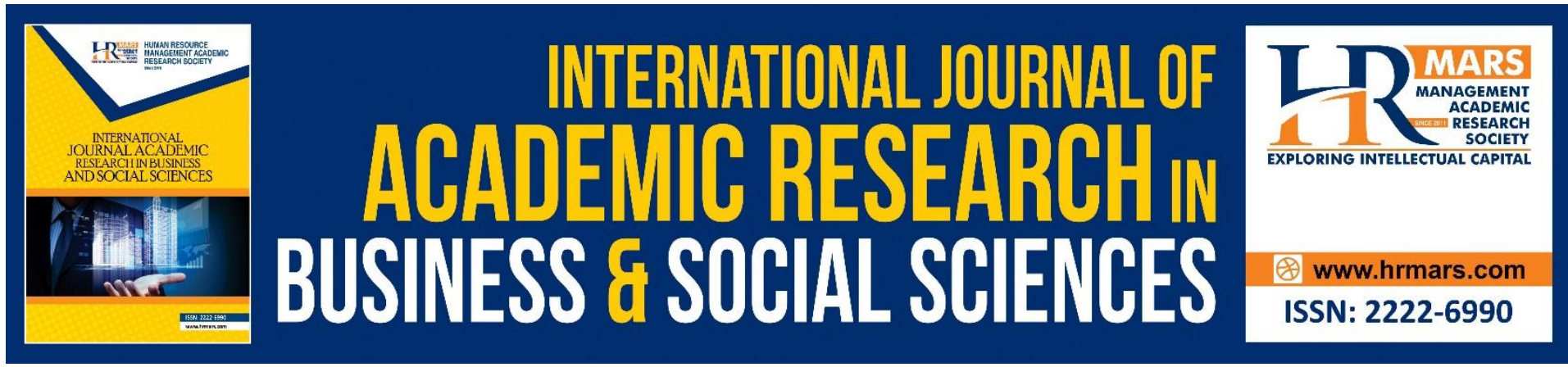

\title{
TVET Graduate Employability: Mismatching Traits Between Supply and Demand
}

\author{
Jeffridzal Bin Ismail ${ }^{1}$, Chemah Tamby Chik $^{2}$, Mohammad \\ Abdullah Hemdi ${ }^{3}$ \\ ${ }^{1}$ Kolej Komuniti Kuala Langat Jalan Sultan Suleiman Shah, Jugra, 42700, Selangor, Malaysia, \\ ${ }^{2}$ Faculty of Hotel and Tourism Management, Universiti Teknologi MARA Cawangan Selangor, \\ Puncak Alam Campus, 42300, Selangor, Malaysia, 3Universiti Teknologi MARA Cawangan \\ Kedah, Merbok Campus, 08400 Kedah, Malaysia
}

\begin{abstract}
Polytechnic programmes in Malaysia were established to produce quality graduates at the semi-professional level in engineering, trade, hospitality, ICT and services, as well as, to provide alternative pathways for TVET students in the higher education. According to the Ministry of Education, even though Polytechnic graduate employability is at $96.7 \%$, the tourism management programmes in Polytechnics have an average of $51 \%$ employability upon graduation, and these deficiencies need to be identified and studied seriously. Research has shown that graduates' employability depended on student and instructor characteristics. However, the main idea of this study is to determine whether the characteristics of an instructor in the industries could act as a mediating factor to contribute to the competency of the TVET students in the tourism management programmes at Polytechnics in Malaysia. According to the social learning theory, human behaviour is learned by observing other people as role models and it could change a person to be better. In the industrial training or workbased learning programmes, instructors' characteristic is seen as a role model to be followed by students to shape their attitudes towards a better job performance and organization achievement. Thus, this paper attempts to discuss student and instructor characteristics and how both traits play a role in graduate employability.
\end{abstract}

Keywords: Employability, Instructor Characteristic, Student Quality Characteristics, TVET, Work-Based Learning.

\section{Introduction}

\section{Background of the Study}

The rapid growth in the number of Malaysian higher education institutions is aligned with the government's agenda to prepare a skilled and professional workforce, and eventually to achieve the status of a developed country in the year 2020 (Economic Planning Unit, 2015). However, Malaysia is still far from achieving developed country status. Presently, there are 20 fully-fledged public universities and 38 private universities in Malaysia (Venesa, 2019). These higher institutions produce 
an average of 150 million students every year (Graduate Tracer Study, 2019). In a challenging economy, the role of higher education institutions is not only to produce graduates with specific areas of specialization but more importantly, to develop graduate employability skills that are most demanding in the 21st Century and Industry Revolution 4.0 (Jabatan Pendidikan Politeknik dan Kolej Komuniti, JPPKK, 2019; Ministry of Education, MoE, 2019).

Although both public and private institutions produced about 29,0282 graduates in 2018 (Ministry of Education, MoE, 2018) with the numbers increasing yearly, the demand for this skilled workforce is not in tandem with the production. The areas which are affected most are the manufacturing and services sectors such as food and beverage, art, entertainment and recreation, and other services such as beauty and saloon. This issue has been an area of concern for the Government because if the increasing number of graduates are not aligned with the number of jobs created, this could contribute to a serious unemployment problem in the country (Azmi, Hashim, and Yusoff, 2018) and later create an imbalance between workforce supply and demand (Institute of Labour Market Information and Analysis, ILMIA, 2018; Ministry of Finance, MoF, 2020). As a consequence, some graduate employees only managed to get jobs that are below their qualifications (Salina, Nurazariah, Noraina Mazuin, and Jagatheesan, 2011). The researchers identified that graduate unemployment is due to the industry-academia widening gap of mismatching graduates' skills with industrial demands (Azmi et al., 2018; Baqutayan, Bizanjo, Raof, and Kadir, 2019; Venesa, 2020). The Department of Statistic Malaysia (2016-2018) stated that there were 162,000 unemployed graduates in 2018, an increase of 4.6 percent from 2017, 154,900 persons. The number of unemployed graduates is predicted to increase due to the spread of the COVID-19 pandemic in the world. This pandemic has affected all sectors in Malaysia's economy, with the tourism industry affected the most (Ministry of Tourism Art and Culture Malaysia, MoTAC, 2020).

In the Technical and Vocational Education and Training (TVET) education system, students are required to achieve a standard of competency framed by the Malaysian Qualification Accreditation (MQA). All the domains listed in the code of practice are based on viewpoints from the industry and main players in the tourism sector compared with the academic education where more focus are given to the Cumulative Grade Point Average (CGPA). Students are required to be competent during their practical to be awarded good results. However, internship will be evaluated by the instructor in the industry along with the internship process (Zaipah et al., 2014). Instructors in the industry involved in education and training processes will assess students to determine the effectiveness of training and skills provided. Competency-based assessment is important to verify that the person has demonstrated practical skills and basic knowledge required to perform duties in accordance with certain standards (ILMIA, 2018). In this evaluation method, instructors in the industry act as a mediator in the evaluation of students' performance. Several studies (Wu et al., 2019; Orgambídez and Almeida, 2019) contended that, instructors play a role as moderators in motivating employees to achieve the organization target, while Obuobisa-Darko (2020) stated that instructors' engagement with their workers will drive them to have positive emotions imbued with optimism, energy, high level of job focus, optimistic, energetic, focus highly on work, and willing to work for the development of the organization. 
According to (Hassan, 2012), student quality include acquiring the expertise needed in their jobs, possess cognitive coupled with functional work skills, have personal entrepreneurial skills, and professional ethics. Discussions on student quality and competencies also include students' ability and willingness to learn, teamwork and cooperation, hardworking and willingness to take on extra work, self-control, and analytical thinking (Pang et al., 2019; Kenayathulla, Ahmad, and Idris, 2019), ability to cooperate effectively and lifelong learning (Dušek, 2019). Besides the student competencies, instructor traits and characteristics are also important.

Therefore, to achieve student competency and effectiveness in facing the Industrial Revolution 4.0, the MQA has listed five elements in student evaluation that instructors need to know in assessing students during their internship and all the elements are listed from direct feedback from the industries involved in the TVET field (Malaysian Qualifying Agency, MQA, 2019; Ismail and Hassan, 2012). These elements contribute to graduate employability and it has been decided that these five elements will form the core of the evaluation for TVET programmes in Malaysia. These elements are: (a) knowledge and understanding, (b) cognitive skills, (c) functional work skills with a focus on practical skills, interpersonal skills, communications skills, digital skills, numeracy skills, and leadership, autonomy and responsibility, (d) personal and entrepreneurial skills, and (e) ethics and professionalism. A right evaluation guideline could give an impact on graduate competency and employability (Ismail and Hassan, 2013). However, a competency-based assessment is strongly required for TVET students compared to the academic students, where most industries are looking for students with higher competency skills and good in soft skills such as communication skills, leadership skills, managerial skills, personality and attitude that contribute to the company profits and growth (Ismail and Abiddin, 2014).

According to the past studies, besides the qualification level mismatch, skills, and knowledge mismatch, instructor characteristics is one of the aspects that contribute to the competency of the interns (Ismail and Hassan, 2012; Carless, Robertson, Willy, Hart, \& Chea, 2012). Furthermore, instructors are referred to as facilitators, peer instructors, preceptors, clinical guiders, trainers, mentors, clinical instructors and/or supervisors. Instructors are defined as employees of an organization who have been appointed by the industry (employer) and agreed upon by the higher education institution to teach, guide, mentor, and assess the TVET students at the workplace in order to achieve the programme learning outcomes and objectives of the TVET programmes, as framed by the Ministry of Higher Education Malaysia. Commonly, mentors are not employed by the educational provider. Furthermore, in many European countries, mentors are not required to complete any mentoring education prior to their mentoring a student (Tuomikoski et al., 2020).

Omar, Zahar, and Rashid (2020) stated that, the quality of instructors in knowledge delivering and transferring experience during student induction, training, apprentice, or onjob training also contribute to the competency and employability of TVET programmes in the Polytechnic. Instructors should be armed with good leadership skills and the right mindset so that they will be competent enough to train and deliver their knowledge and skills to trainees. Prunuske, Houss, and Kosobuski (2019) and Fard et al (2020) pointed out that, it is important to have an instructor during the internship where mentor-peer will transmit the 
experience, knowledge, and professionalism and at the same time knowledge could be applied broadly across the school curriculum. Xiong, Lin, Li, and Wang (2016) stated that instructors or leaders could react as mediators, based on their roles in their hierarchy or positions in order to influence subordinates to fulfil their job satisfaction. In this study, it is necessary to know how instructors play their roles as mediators in developing student competency. In the context of mentor-mentee, the researchers (Cha et al., 2020; Prunuske et al., 2019; Ward et al (2020) advocated that mentorship programme helped participants improve their professional skills, be more competent in designated tasks, interpersonal skills, communication skills, professional skills, help students finish their tasks and assessment within a shorter time frame and help pull the protégé up the organizational structure (Ferrández-Berrueco, Kekale, \& Devins, 2016) and increase organizational commitment (Lapointe and Vandenberghe, 2017). Instructors' knowledge added with vast experience, will help in student employability and work skills (Meza et al., 2018).

Research found that systems-thinking, strategic, anticipatory, normative and interpersonal, effective mentor, able to spend time with, communicate or respond effectively to the student, ability to encourage, high level of professional skills, pedagogy skills, disciplined, supportive, motivating and ability to lead others, ability to convey constructive and thoughtful criticism in a patient and sensitive manner would help to foster student competencies and skills in the TVET field (Prunuske et al., 2019; Mohtady et al., 2019); Herlandy, 2019). It is advocated that TVET must be designed and monitored by someone who understands about the working process in the company and the things students need to learn during the internship (McGee, 2017; Moses, 2016). Instructors should help students by providing frequent feedback about students' work and learning performance (Morley, 2018). Instructors are responsible for industrial training in the teaching context, supporting and evaluating student performance, and is also a key element in the coaching process during internship (Malaysian Qualifying Agency, 2016).

Instructor roles in the TVET education is an important aspect to be taken into account in order to build a strong TVET education system in Malaysia. The social learning theory indicates that students benefit from their instructors through career support and psychosocial support, and a role model in which to base their actions and behaviours. It may be through this "on-the-job" learning and - associating with a successful role model represented by the instructor, which may help reduce role ambiguity and increase the mentee's role clarity (Brashear-Alejandro, Barksdale, Bellenger, Boles, and James, 2019). Thus, the researchers stressed the importance of instructor roles as a major factor that can affect directly student competency and performance, contributing to the development and acquisition of the necessary job skills required to function at the workplace. Previous research found that mentor-mentee programme influences the relationship between employees' trust in their supervisors and their affective levels, job performance, job satisfaction, length of stay in the organization, upgrade their knowledge and skills for career development, effectiveness and competence (Jyoti and Sharma, 2017; Arora and Rangnekar, 2015; Xiong et al., 2016).

According to (Hasan, 2012), studies related to criteria in selection of instructors is still lacking, especially in the TVET education field. The results of the studies on mentoring programmes 
published in the 21st century reveal that instructors' ability to relate psychosocial factors and career development can have a significant impact on student achievement, career satisfaction, work (Lunsford, Baker \& Pifer, 2018), and career motivation (Kao, Rogers, Spitzmueller, Lin, and Lin, 2014; Abdullah, Ismail, Nor, Hasand, \& Ehsan, 2020). Although the nature of this relationship has been extensively studied, the role of the instructor as a mediator is not explored in detail in the literature review of mentor-mentee programmes (Jyoti and Sharma, 2017; Washington and Cox, 2016).

Previous studies have used simple correlation methods, namely measuring the degree of relationship strength and the direction of the relationship between the instructor role and student career success, as well as explaining the differences of respondents' views on instructor role (Jyoti and Sharma, 2017). To date, most of these studies have not focused much on assessing the size of the impact of the instructor's role as predictor of student career success and competencies. Therefore, the general recommendations do not suffice as appropriate and effective guides to be used by practitioners to understand the complexities of the concept of the mentor-mentee programme aimed at increasing instructors' capabilities to guide students to achieve and maintain student competitiveness. In the context of TVET education, there is no emphasis on the role of instructors as predictive variables (mediator or mediate) that are important to the success of student achievement. Thus, this situation inspires researchers to fill the gaps in the literature review by assessing the impact of the instructors' role on student success and competency.

Hence, with the existing problems, this study is conducted to identify the instructor characteristics as a mediating factor that contributes to graduate employability and skills, the significance of student evaluation or enhancement, and graduate employability in Tourism Management programme in TVET institutions in Malaysia. This research is important to explore why most of the Tourism Management graduates in Polytechnic Malaysia only make up for $51 \%$ of the tourism job field and many graduates pursue further studies in the same programmes in local universities, while the rest are employed in other sectors such as retailing and services (Graduate Employability Department, JPPKK, 2020).

\section{Literature Review \\ Graduate Employability}

Employability is defined as a set of achievements, understanding and personal attributes that make individuals more likely to gain employment and be successful in their chosen occupations. Meanwhile, Holmes (2013) define employability as the generic skills, attitudes, and behaviours that employers look for. Oliver (2015) as cited in Winberg et al., (2020) proposed that employability is the ability to discern, acquire, adapt, and continually enhance the skills, understanding and personal attributes that make students/graduates more likely to find and create meaningful paid and unpaid work that benefit themselves, the workforce, the community, and the economy.

Since 1980, Malaysia's participation in the workforce has been on an upward trend, gaining annual net employment creation. Malaysia's labour force increased $2 \%$ to nearly 15 million in 2017 and unemployment rates remained the same as of 2016 at 3.4\% (DOSM, 2017). Most of the Malaysians worked full-time (97\%), the majority of which were semi- 
skilled (62\%), followed by skilled (23.5\%) and low-skilled (14.5\%) (DOSM, 2017). The employment breakdown by sectors indicated over half of Malaysia's workforce are employed in services (54.9\%), followed by manufacturing (24.3\%), construction (14.8\%), agriculture (5.1\%) and mining and quarrying (0.9\%) (DOSM, 2017).

According to the Higher Education Department, graduates are facing huge employability issues, where within six months of graduating, the graduate employability rate for 2018 was at $80.2 \%$ where $58.6 \%$ obtained jobs in entrepreneurship; $15.7 \%$ furthered their education; $1.3 \%$ underwent training for skills improvement, and $4.6 \%$ waited for job placements. The Graduate Tracer Study (2019) found that it was also crucial to note that the graduate employability rate had increased between 2017 and 2018 by $1.1 \%$.

In line with the above notion, graduate employability is one of the main agendas and this issue - is of grave concern for the government and other related ministries such as the Ministry of Education, Ministry of Human Resources, Economic Planning Unit, and Department of Skills Development (MQA, 2019). The ministries, together with the higher education institutions and the industries, are working together to ensure that graduates meet the requirements of the job market. Among the initiatives that have been planned and are continuously carried out include, industry involvement in curriculum, value infused talent, and intervention programs to increase graduate employability.

The former Deputy Minister of Education, point that demand for TVET graduates in Malaysia is expected to increase to 7.98 million by the year 2030, when it was only about 6.6 million in 2015 and expected to rise to almost 8 million in about 30 years. The employability of TVET graduates could go as high as $96 \%$ while the figures for public and private universities stands at about $80 \%$ and $72 \%$ respectively and at the moment, Malaysia does not have enough TVET graduates for the industry.

On reflection, the ministry has also set up the national-level TVET Empowerment Committee to develop new policies that are relevant to industrial needs. The industry representatives have been actively involved in developing academic programs, mentoring lecturers and students, as well as, providing industrial experience to the students via practical training, internship programs, work-based learning (WBL), 2u2i, Problem Based-Learning $(\mathrm{PBL})$, Work-Integrated Learning (WIL), Service Learning Malaysia: University for Society (SULAM). Many more programs have been drafted and framed to match with the industrial needs and demands in order to increase graduate employability and to reduce unemployment among graduates in Malaysia.

All these efforts are being catered by the Polytechnic and Community College in Ministry of Education, Malaysia. This department has been producing TVET students and graduates for Malaysian industries. Amongst all, its mission is to produce skilled and semiskilled graduates in the areas of manufacturing, engineering, business and management, and hospitality. 


\section{Background of Polytechnics in Malaysia}

Polytechnics were established since 1969 with aims to provide education and training in engineering and commerce at the technician and junior executive levels (such as engineering technicians, technical assistants, and business personnel). With the current push towards economic expansion and industrialization, the role of the polytechnics is quickly taking the centre stage. There are seven polytechnics, as indicated in Table 1 (JPPKK, 2019).

Table 1: List of Polytechnics with Its Area of Specialization

\begin{tabular}{|c|c|c|}
\hline Polytechnic & Area of Specialization & Programs Offered \\
\hline Politeknik Ungku Omar, Perak & $\begin{array}{l}\text { Engineering, } \\
\text { Commerce and } \\
\text { Services Sectors }\end{array}$ & $\begin{array}{l}\text { *Civil Engineering } \\
\text { *Electrical Engineering } \\
\text { *Mechanical Engineering } \\
\text { *Marine Engineering } \\
\text { *Commerce } \\
\text { *Information \& Technology } \\
\text { *Mathematics, Science \& Computer } \\
\text { *General Studies }\end{array}$ \\
\hline $\begin{array}{l}\text { Politeknik Sultan Haji Ahmad } \\
\text { Shah, Pahang }\end{array}$ & Engineering, Trade & $\begin{array}{l}\text { *General Studies } \\
\text { *Civil Engineering } \\
\text { *Mechanical Engineering } \\
\text { *Electrical Engineering } \\
\text { *Food Technology } \\
\text { *Mathematics, Science and } \\
\text { Computer } \\
\text { *Department of Commerce }\end{array}$ \\
\hline Politeknik Batu Pahat, Johor & Engineering, Education & $\begin{array}{l}\text { *Certificate in Technical Education } \\
\text { *Bachelor of Science in Civil } \\
\text { Engineering } \\
\text { *Electrical and Mechanical } \\
\text { Engineering and } \\
\text { *Technical Education }\end{array}$ \\
\hline $\begin{array}{l}\text { Politeknik Sultan Abdul Halim } \\
\text { Mu'adzam Shah, Kedah }\end{array}$ & Engineering, Trade & $\begin{array}{l}\text { *General Studies } \\
\text { *Civil Engineering } \\
\text { *Mechanical Engineering } \\
\text { *Electrical Engineering } \\
\text { *Food Technology } \\
\text { *Mathematics } \\
\text { *Science and Computer, } \\
\text { *Commerce }\end{array}$ \\
\hline $\begin{array}{l}\text { Politeknik Kota Bharu, } \\
\text { Kelantan }\end{array}$ & Engineering, Trade & $\begin{array}{l}\text { *Civil Engineering } \\
\text { *Electrical Engineering } \\
\text { *Mechanical Engineering } \\
\text { *Trade }\end{array}$ \\
\hline Politeknik Kuching, Sarawak & $\begin{array}{l}\text { Engineering, Trade, } \\
\text { Information } \\
\text { Technology }\end{array}$ & $\begin{array}{l}\text { *Civil Engineering } \\
\text { *Mechanical Engineering } \\
\text { *Petrochemical Engineering }\end{array}$ \\
\hline
\end{tabular}




\begin{tabular}{|c|c|c|}
\hline & & $\begin{array}{l}\text { *Electrical Engineering } \\
\text { *Information Technology and } \\
\text { Communication, } \\
\text { *General Studies, } \\
\text { *Trade }\end{array}$ \\
\hline $\begin{array}{l}\text { Politeknik } \\
\text { Port Dickson, Negeri Sembilan }\end{array}$ & $\begin{array}{l}\text { Engineering, Trade, } \\
\text { Services Sectors }\end{array}$ & $\begin{array}{l}\text { *Civil Engineering } \\
\text { *Electrical Engineering } \\
\text { *Trade } \\
\text { *Mathematics, Science and } \\
\text { Computer }\end{array}$ \\
\hline
\end{tabular}

The TVET programmes at Polytechnics in Malaysia began with the establishment of Ungku Omar Polytechnic, Ipoh Perak in 1969 under the United Nations Development Plan. TVET was given prominence by the Cabinet Committee on Education in 1979 and the First National Industrial Plan (1985-1995). In addition to the decisions made by these committees, the Cabinet Committee on Training (1991) paved the way for the significant development in Polytechnic education. As a result, there was an increase in the number of polytechnics built and these institutions were able to offer more programmes of study to cater for the demands of skilled human resources in engineering, commerce and services sectors. To further reinforce the roles of polytechnics and community colleges in education and training, the cabinet deliberated and approved the merger of polytechnics and community colleges under one department on 24th March, 2017. In addition to that, the Public Service Department endorsed the new organization structure of the Department of Polytechnic and Community College Education on 23rd February 2018. It has enabled the establishment of more polytechnics as well as increased study programmes to meet the needs of semi-professional workers in the fields of engineering, trade and services. The Cabinet on 26 March 2010 considered the Memorandum of Higher Education (No. 198/2685/2010) and agreed to establish four METrO Polytechnics under the ninth Malaysia Plan and six under the $10^{\text {th }}$ Malaysia Plan.

The programmes at the seven polytechnics comprise full-time certificate and diploma courses. The Certificate is a four-semester course with a two-year duration. Students who consistently maintain a high standard will be considered for extension for another year to obtain a Diploma in their related field. The Diploma courses are of three years' duration (except Marine engineering; four years and Secretarial; two years). All polytechnic courses include a sixth-month industrial attachment in the public or private sector during the third semester. This stimulates students' innovative capabilities and gives ample scope for acquiring the skills in the broadest sense. The courses at the polytechnics are conducted by four departments which are commerce, civil, electrical, and mechanical engineering.

Generally, all the seven polytechnics are self-contained. They provide residential, recreational and worship facilities which include cafeteria, co-operative store and a bookshop, all meant to cater to the daily needs of students and staff. The Technical and Vocational Education Division is responsible for the organization, management and supervision of the educational programs and activities of vocational and technical schools 
and polytechnics. The Division also works closely with other agencies involved in training of semi-skilled and skilled manpower such as the National Vocational Training Council.

By the year 2020, Malaysia had established 36 polytechnics where three are premier polytechnics, 28 - conventional polytechnics, five METro polytechnics and eight of them are the leading Centres of Technology. Polytechnics offer 94 full time programs, nine bachelor's degree, 78 diploma, two pre-diploma and five skills certificate level programs. According to the Graduate Employability Department, polytechnics have contributed $95.4 \%$ of the semiprofessional workforce required by the labour market. This represents 96,370 of the total student enrolment and from this total enrolment, 646 are with a bachelor's degree, 94,551 with a diploma, 968 with a pre-diploma, 205 with a skills certificate graduates.

\section{Tourism Management Programme in Polytechnic}

Polytechnic is one of the institutions that offer tourism courses in Malaysia. The implementation of learning and practice is based on a hands-on approach where 60 to 70 percent of the learning delivery is based on practical or on-the-job-training perspective. The Bachelor of Science in Tourism and Hospitality Management with Honours Programme is a bachelor's degree programme that differs from the other programs using the Work-Based Learning (WBL) approach. WBL allows students to gain optimal skills and knowledge in their field of choice and in selected industries for a period of 12 months. Students will follow some of the conventional learning on campus and some of the modules are covered in the industry. This provides a vast experience and opens the space for students to place themselves in their field of interest. Students also have the opportunity to establish their relationships with the potential employers in the near future, thus improve their marketability.

The main objective of this program is to produce graduates with soft skills, industrial development and research methodology skills to meet the needs of the multidisciplinary in the 21th century and the Industrial Revolution 4.0, as well as, improve their eligibility to occupy positions at the management and professional levels. The development of this Tourism Management Programme in polytechnics is based on the industrial needs and demand and will adopt a WBL approach where students will be exposed to a lot of practical work involving hands-on training, and the work situations require students to apply soft skills through applied-based learning. Students will also have the opportunity to be exposed to international industrial experience.

\section{Assessment in Polytechnic The WBL Approach}

According to the previous research and findings, WBL represents a relevant approach to produce the required workforce for the present day job market and this approach has been practiced all over the world for decades. Previous research done by Coll and Zegwaard (2012) found that, this is an active and dynamic form of learning that slowly develops throughout the lifetime of an individual. WBL is suitable for use in tertiary education and applicable in the TVET except for academic disciplines such as the economics and business sciences (Stones, 
1994). WBL is a learning model whose application is effective in improving cognitive, affective, and psychomotor aspects (Marlina, 2019). It is widely acknowledged that WBL is a strategy to boost future development of the existing workforce in many countries.

According to Anuar, Sultan, and Shah (2019), one of the models used to practice WBL is the Arizona Work-Based Learning Resource Guide Model. Figure1 shows the WBL implementation model in Arizona. WBL creates a two-way relationship between the educational institution and the industry through various activities and resources. A strong two-way relationship could make the WBL method more efficient and effective (Otala, 1994).

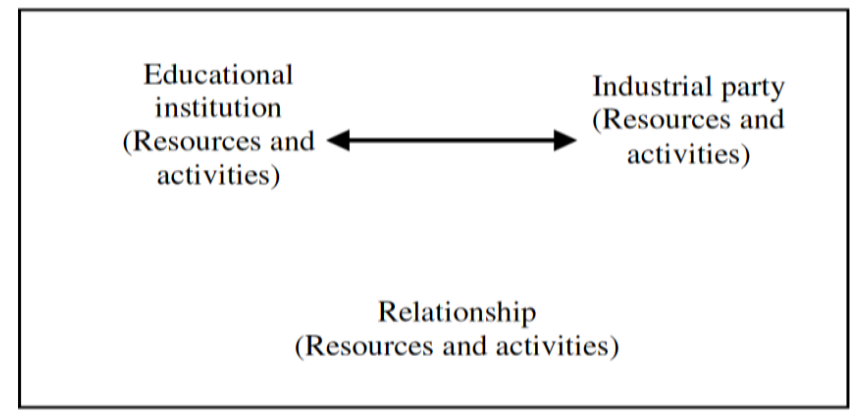

Figure 1: The WBL-Arizona work-based learning resources guide model

Another model is the Developing European Work Based Learning Approaches and Methods (DEWBLAM) project with the objective of developing a Europe-wide network of models and approaches to WBL within a European consortium of establishments. This model allows adults who are currently employed to get a higher education qualification, through accreditation of prior and experiential learning (Lemanski, Mewis, and Overton, 2011). Where students are full-time employees, the program of study is embedded in the workplace and is designed to meet the learning needs of the employees and the aims or objectives of the organization. WBL is a form of learning that relates to all fields of work, work-based learning, learning at the work place and learning through working (Brennan and Little, 1996).

WBL is a learning approach that involves working experience in which students need to go through a learning process in an institution or organization to gain the experience and apply the skills in the related industries according to what is required in an actual working environment (Musset, 2019). WBL is an approach used for students at school level for them to obtain experience through work. This transitionary stage from institution to work place enables students to adapt themselves to the realities of the working environment allowing them to make better career choices (Coll et al., 2009) as cited in (Stirling et al., 2016). In addition, Seufert (2000) stated that WBL unites theory with practice, knowledge with experience.

Other researchers found that WBL is a term being used to describe a class of university programmes that brings together universities and work organizations to create new learning opportunities in workplaces (Kerka, 2002). In another research, Sobiechowska and Maisch (2006) found that, WBL is one of the learning methods where students are 
required to comply with the company work culture and the learning structure are designed to fulfil both needs. In addition, the term WBL can also be used to describe a diverse range of learning situations which have different influences on higher education providers, students, employers, and employees.

In Malaysia, WBL was started in 2007 after community colleges collaborated with industries, resulting in the two parties signing a memorandum to cooperate with each other to run this program. Community Colleges were the first educational institutions to be given the responsibility to implement the WBL program; this was followed by polytechnics in July 2010. The introduction and running of WBL is under the purview of the Ministry of Education Malaysia. The term WBL has been applied to situations where students' learning is associated with the requirements of the job sector; students learn to perform tasks and carry out responsibilities through work assigned to them during their industry attachment. In the context of polytechnic education and community colleges, WBL is defined as a structured learning approach that provides students with real work experience through an immersive program guided by industry practitioners who are able to contribute to graduate marketability (Coppa, 2018).

According to (JPPKK 2019), the implementation of teaching and learning in WBL approach should be based on the curriculum structure of the program developed in accordance with best practice guidelines as well as set standards and qualification frameworks. WBL in polytechnics is a structured teaching and learning activity that involves work experience in an industrial environment based on three main components; students, institutions, and industry. The practice of the WBL approach is basically in accordance with specific requirements of the relevant programs and industries and is conducted for a minimum of one semester and a maximum of two semesters through block release delivery methods in the industry. There is no specific model for the implementation of the WBL study program at the polytechnics, or in other words there is no "one fit for all" models adapted by each program (JPPKK, 2019).

\section{Instructor Characteristics in TVET Programmes}

In the context of TVET programmes, mentor-mentee is a method used to successfully guide the mentee in achieving organizational goals and, to enhance the acquisition of relevant knowledge and skills for jobs in the market (Abdullah, Ismail, Nor, Hasand, and Ehsan, 2020; Okolie, Nwajiuba, Binuomote, Ehiobuche, Igu, and Ajoke, 2020). In addition, mentoring can develop self-efficacy through the other three processes (vicarious experiences, verbal persuasion, and physiological and emotional states (Bandura, 1977) as cited in Nabi, Walmsley, and Akhtar (2019). The role played by instructors is one of the elements that contributes to the effectiveness of student performance on the job training and their employability upon graduation. Throughout this process, students' confidence level, knowledge and effectiveness in communication can be improved. Terry, Nguyen, Perkins, and Peck (2020), contended that, the dynamics of the supervisory relationship are also mediated by elements that may be considered external to the relationship, but have implications on their effectiveness. 
An effective teaching and learning process, which results in developing students' competence to perform in the job market, demands instructors to execute their roles in a responsible and effective manner (Fisher, 1994; Higher Education Quality Council of Ontario, 2016) The importance of instructors' role in students' growth and competency is further reiterated by Arora (2020). Okolie et al., (2020) stated that, instructors may not always create positive career development, but they can serve as good mediums to aid less experienced people to develop their careers and also prevent career thwarting or frustrating behaviour. Several researchers (Baluku et al., 2019); BarNir, Watson, \& Hutchins, 2011; Johannisson,1991; McGowan et al., 2017) as cited in Kubberød, Fosstenløkken, and Erstad (2018) agreed that, instructors can support self-efficacy development through vicarious experiences by becoming role models, allowing mentees to evaluate and improve their entrepreneurial and business skills through social comparison and imitative behavioural strategies. Furthermore, mentors serve as key sources for ensuring the continuation of knowledge within organizations and for grooming junior employees (Allen, 2012).

According to Arora (2020), there are two categories of mentoring functions - one is the psychosocial function, whilst the other, career mentoring functions, with both constituting the social-exchange process. Additionally, in the context of training in the industry, instructors are responsible for executing their roles through teaching, supporting, and evaluating student achievement which are key elements in the coaching process (Davies, Neary, and Phillips, 1994). To ensure that the instructors realize their roles effectively in the teaching process, instructors need to be able to teach, be a good speaker, knowledgeable in their field, set realistic expectations for students, giving time to learners through learning to execute (Kindle Version, 2017). In addition to teaching, instructors generally play roles as instructors and facilitators by providing support in education as well as facilitating students, promoting good relationships, and advising students and providing learning resources (Neary, 2000).

The University of British Colombia (2004) explained that to improve the effectiveness of student coaching, institutions should first identify the effectiveness of their instructors by obtaining feedback from students or conducting self-assessment. (Lascelles, 2016) stated that assessment of instructors as effective guides, can be measured through (a) selfassessment by instructors, (b) student based surveys, (c) peer evaluation (d) obtaining data from students or staff through their perception of instructors' contributions in the professional and personal development of students, (e) obtaining data from students or staff through their observation of the performance of instructors, and ( $f$ ) through monitoring and evaluation of the industry manager, lecturer or lead counsel.

Instructors play a very important roles in promoting TVET and skills development programs where students are able to improve their work efficiency and productivity. The role of instructors has become a mediating factor in facilitating individual learning and the development of student skills and competency. Therefore, to become an instructor, the individual must display sufficient readiness from various aspects before assuming responsibility and performing the role of an instructor. Effective instructors are able to assist students by increasing their self-esteem and giving them a high level of job satisfaction. The 
existence of instructors benefit all parties involved in the implementation of TVET programmes.

Individuals involved in TVET programmes must have knowledge in implementing them. They must be knowledgeable in performing their roles as instructors to make WBL programmes effective. Fisher (1994) contended that, effective instructors are knowledgeable and willing to share their knowledge, not only in their field, but also procedures and policies of the company and institutions involved. Instructors' skills and their ability to foster a good classroom environment, and mentors' accessibility, are factors that enable the learning and promote the well-being of student performance (García et al., 2020; Prunuske et al., 2019). The instructors must also have competencies as mentioned by Tuomikoski et al., 2020). An ideal instructor also needs to have knowledge of the organization and share that knowledge along with the student.

Spencer (2004) explained that several important factors should be considered when choosing instructors, which include extensive experience and knowledge, flexibility and progressive management styles especially in human management, ability to develop the skills and knowledge of the students and open and honest in sharing knowledge and experience, reliable consultants as well as coaches to promote growth of good relationships, good interpersonal skills and aware of their job responsibilities in supporting staff. Spencer (2004) allen added that, TVET programs will be effective in producing the desired outcomes if each instructor is prepared before becoming and also upon assuming that role, to commit to performing the duties and responsibilities by observing the characteristics and criteria of effective instructors. Hence, this study is conducted to obtain insight into effective instructor characteristics and identify those characteristics and criteria to ensure that TVET students develop those competencies stipulated by MQA. It has been mentioned previously by many scholars that characteristics of effective instructors is an area where limited research has been carried out.

\section{Conclusion}

After deliberating on student and instructor characteristics, this study is deemed necessary to look into the mismatch between graduate students' competencies and industry expectations which has impacted their employability. The characteristics will be identified to provide answers to the present lack of knowledge in this area in the hope of fulfilling the expectations of both stakeholders, be it the industry and the learning institutions. This will further prepare graduates to be better equipped with the technical, communication, and psychosocial skills for their career development. More specifically, findings from this study will substantially expand the body of knowledge related to instructor characteristics in the TVET field, and improve the competency issues among tourism students in the Malaysian polytechnics and contribute towards the graduate employability target set by the Ministry of Education Malaysia.

\section{Acknowledgment}

The authors would like to thank the Department of Technical and Vocational, Ministry of Education for its assistance in providing basic data on the TVET programmes in Malaysian Polytechnics. 


\section{Corresponding Author}

Chemah Tamby Chik.

Faculty of Hotel and Tourism Management, Universiti Teknologi MARA Cawangan

Selangor, Puncak Alam Campus, 42300 Selangor, Malaysia.

Email: chemah@uitm.edu.my

\section{References}

Abdullah, N. A., Ismail, A., Nor, A. M., Hasand, N. A., \& Ehsan, S. D. (2020). Peranan Mentor Dalam Meningkatkan Kejayaan Kerjaya Menti : Satu Kajian Di Jabatan Perkhidmatan Awam Malaysia [Mentors' Roles In Enhancing Mentee' S Career Outcomes : A Case Of Malaysian Public Sector] Oswatun Samate Institute Islam Hadhari , Universit. Journal Of Nusantara Studies 2020, 5(1), 315-335.

Arora, R. (2020). Mediating role of mentoring functions on linking personality and occupational commitment in Indian organizations. Human Resource Development International, 23(3), 283-308. https://doi.org/10.1080/13678868.2020.1727218

Arora, R., \& Rangnekar, S. (2015). The joint effects of personality and supervisory career mentoring in predicting occupational commitment. Career Development International, 20(1), 63-80. https://doi.org/10.1108/CDI-12-2014-0156

Allen, T. D. (2012). Mentoring Relationships from the Perspective of the Mentor. The Handbook of Mentoring at Work: Theory, Research, and Practice, 123-148. https://doi.org/10.4135/9781412976619.n5

Anuar, S., Sultan, P., \& Shah, A. (2019). MODEL -MODEL PEMBELAJARAN BERASASKAN KERJA (WORK BASED. (June).

Azmi, I. A. G., Hashim, R. C., \& Yusoff, Y. M. (2018). The employability skills of Malaysian university students. International Journal of Modern Trends in Social Sciences, 1(3), 0114.

Baluku, M. M., Leonsio, M., Bantu, E., \& Otto, K. (2019). The impact of autonomy on the relationship between mentoring and entrepreneurial intentions among youth in Germany, Kenya, and Uganda. International Journal of Entrepreneurial Behaviour and Research, 25(2), 170-192. https://doi.org/10.1108/IJEBR-10-2017-0373

BarNir, A., Watson, W. E., \& Hutchins, H. M. (2011). Mediation and Moderated Mediation in the Relationship Among Role Models, Self-Efficacy, Entrepreneurial Career Intention, and Gender. Journal of Applied Social Psychology, 41(2), 270-297.

https://doi.org/10.1111/j.1559-1816.2010.00713.x

Baqutayan, S., M., S. Bizanjo., M., G., Raof., N., A., A., \& Kadir, Z., A., (2019). Fostering graduate employability in Malaysia - bonding both industry and academia with a proper monitoring system. Journal of Science, Technology and Innovation Policy, 5(1), 1-13.

Bandura, A. (1977). Self-efficacy: Toward a unifying theory of behavioral change. Psychological Review, 84(2), 191-215. https://doi.org/10.1037/0033-295X.84.2.6 A.

Brashear-Alejandro, T., Barksdale, H., Bellenger, D. N., Boles, J. S., \& James, C. (2019). Mentoring characteristics and functions: Mentoring's influence on salespeople. Journal of Business and Industrial Marketing, 34(2), 303-316.

Brennan, J., \& Little, B. (1996). A review Of work-based learning in higher education, Department of Education and Employment, Quality Support Center, Open University. Sheffield, P118-199 
Carless, S. A., Robertson, K., Willy, J., Hart, M., \& Chea, S. (2012). Successful Postgraduate Placement Experiences: What is the Influence of Job and Supervisor Characteristics? Australian Psychologist, 47(3), 156-164. https://doi.org/10.1111/j.17429544.2012.00085.x

Cha, C., Hwang, H., An, B., Jeong, S., \& Yang, S. J. (2020). Nursing student and faculty competency improvement through a nurse-bridging program in Cambodia. Nurse Education Today, 93(June). https://doi.org/10.1016/j.nedt.2020.104523

Coll, R. K., \& Zegwaard, K. E. (2012). An international perspective of cooperative and workintegrated education: A synthesis of themes from the second edition of the international handbook for cooperative and work-integrated education. Australian Collaborative Education Network National Conference. Retrieved from http://acen.edu.au/2012conference/wp-content/uploads/2012/11/90_AnInternational-Perspective-of-Cooperative-and-Work.pdf

Coll, R., Eames, C., Paku, L., Lay, M., Hodges, D., Bhat, R., ... Martin, A. (2009). An exploration of the pedagogies employed to integrate knowledge in work-integrated learning. Journal of Cooperative Education \& Internships, 43(1), 14-35. Retrieved from http://www.tlri.org.nz/

Cooper, A.M. \& Palmer, A. (2000). Mentoring, Preceptorship and Clinical Supervision: A Guide to Professional Roles in Clinical Practice. 2nd. Edition. Oxford: Blackwell Scientific Publication.

Clinkard, K. (2018). Are employability and entrepreneurial measures for higher education relevant? Introducing AGILE reflection. Industry and Higher Education, 32(6), 375-390.

Davies, B., Neary, M., and Phillips, R. (1994) The practitioner-teacher: A study in the introduction of mentors in the pre-registration nurse education programme in Wales. Journal of Advanced Nursing, 23(6), 1080-1088. doi: 10.1046/j.13652648.1996.01163.x.

DOSM. (2017). Department of Statistics Malaysia Press Release Labour Force Survey Report. Department of Statistics, Malaysia (DOSM), (April), 4. Retrieved fromhttps://www.dosm.gov.my/v1/index.php?r= column/cthemeByCat\&cat=126\&bul_id=aEdlelhIVTBtOHhjOUxqcXhyc2pCUT09\&menu_ id=U3VPMIdoYUxzVzFaYmNkWXZteGduZz09

Dušek, R. (2019). Developing student's key competencies through cooperation with enterprises. 5006, 71, 9-11. https://doi.org/10.1051/shsconf/20197105006

Economic Planning Unit. (2015). Rancangan Malaysia Kesebelas (Eleventh Malaysia Plan) : 2016-2020. 1-372. http://rmk11.epu.gov.my/book/eng/Elevent-Malaysia-Plan/RMKe11 Book.pdf

Fard, Z. R., Azadi, A., Khorshidi, A., Mozafari, M., O'Connor, T., Budri, A. M. V., ... Patton, D. (2020). A comparison of faculty led, mentorship program and peer mentoring on nursing students wound dressing clinical skills. Nurse Education Today, 89(May 2019), 104378. https://doi.org/10.1016/j.nedt.

2020.104378

Ferrández-Berrueco, R., Kekale, T., \& Devins, D. (2016). A framework for work-based learning: Basic pillars and the interactions between them. Higher Education, Skills and Work-Based Learning, 6(1), 35-54. https://doi.org/10.1108/HESWBL-06-2014-0026

Fisher, B. (1994). Mentoring. London: Library Association Publishing 
Fleming, J., \& Martin, A. J. (2007). Facilitating reflective learning journeys in sport cooperative education. Journal of Hospitality, Sport, Tourism, Leisure and Education, 6(2), 115-121

García, A. I., Álvarez, T. G., Román, M. D. G., Martín, V. M. G., Merchán, D. T., \& Zamudio, S. C. (2020). University mentoring programmes for gifted high school students: Satisfaction of workshops. Sustainability (Switzerland), 12(13), 1-16.

https://doi.org/10.3390/su12135282

Graduate Tracer Study. (2019). Department of Statistics Malaysia. Press Release. Retrieved from

https://www.dosm.gov.my/v1/index.php/index.phpr=column/cthemeByCat\&cat $=476$

\&bul_id=cDJkZjM5b2hjdjJZMDIvNDlueU54Zz09\&menu_id=Tm8zcnRjdVRNWWIpWjRIb mtlaDk1UT09

Hasan, A. (2012). Instrumen Penilaian Pembimbing Dalam Pelaksanaan Pembelajaran Berasaskan Kerja Pelajar Di Industri (PhD Dissertation, Universiti Teknologi Malaysia). 348.

Higher Education Quality Council of Ontario. (2016). A Practical Guide for Work-Integrated Learning. 192. Retrieved from http://www.heqco.ca/SiteCollectionDocuments/HEQCO_WIL_Guide_ENG_ACC.pdf Herlandy, P. B. (2019). Factors that Contribute to the Achievement of Vocational Competencies of Vocational School Students in Pekan baru. 373, 40-45.

Holmes, L. (2013). Competing perspectives on graduate employability: Possession, position or process? Studies in Higher Education, 38(4), 538-554. https://doi.org/10.1080/03075079.2011.587140

Institute of Labour Market Information and Analysis, ILMIA. (2018). Jobs, Salaries and Vacancies 2017. Retrieved from https://www.ilmia.gov.my/ebook/research/ILMIA_ArtcFREP1_2019_NER2018.pdf

Ismail, A., \& Abiddin, N. Z. (2014). Issues and challenges of technical and vocational education and training in Malaysia towards human capital development. Middle-East Journal of Scientific Research, 19 (February), 7-11.

Ismail, A., \& Hassan, R. (2012). The basis of supervisory practice for vocational education and training. Proceedings Seminar of Postgraduates Education in TVET, 2(1), 18-29. https://doi.org/10.13140/2.1.2547.2322

Ismail, A., \& Hassan, R. (2013). Issues and challenges of technical and vocational education \& training in malaysia for knowledge worker driven. National Conference on Engineering Technology, (January), 12-22.

ILMIA. (2018). Jobs, Salaries and Vacancies 2017. Institute of Labour Market Information and Analysis (ILMIA), 4.

Jabatan Pendidikan Politeknik dan Kolej Komuniti, JPPKK (2019). Kamus KPI 2019. Jabatan Pembangunan Politeknik dan Kolej Komuniti. Retrieved from https://docplayer.info/161477240-Kamus-kpi-2019-versi-2-0-jabatan-pendidikanpoliteknik-dan-kolej-komuniti-galeria-pjh-jalan-p4w-persiaran-perdana-presint-4putrajaya.html

Jabatan Pendidikan Politeknik dan Kolej Komuniti. (2019). Buku Panduan Pelaksanaan Program Pengajian.

Johannisson, B. (1991). University training for entrepreneurship: A Swedish approach. Entrepreneurship and Regional Development, 3, 67-82. 
Jyoti, J., \& Sharma, P. (2017). La investigación empírica de una variable moderadora y mediadora entre el mentoring y el desempeño laboral: modelo estructural. Revista de Psicologia Del Trabajo y de Las Organizaciones, 33(1), 55-67. https://doi.org/10.1016/j.rpto.2017.01.002

Kao, K. Y., Rogers, A., Spitzmueller, C., Lin, M. T., \& Lin, C. H. (2014). Who should serve as my mentor? The effect of mentor gender and supervisory status on resilience in mentoring relationships. Journal of Vocational Behaviour, 85, 191-203

Kenayathulla, H. B., Ahmad, N. A., \& Idris, A. R. (2019). Gaps between competence and importance of employability skills: evidence from Malaysia. Higher Education Evaluation and Development, 13(2), 97-112. https://doi.org/10.1108/heed-08-2019-0039

Kerka, S. (2002). Seufert, S. (2000). Work-Based Learning and Knowledge Management: An Integrated Concept of Organizational Learning. In ECIS (pp. 1413-1420). The Journal of Continuing Higher Education, 50(2), 61-61. https://doi.org/10.1080/07377363.2002.10846683

Kubberød, E., Fosstenløkken, S. M., \& Erstad, P. O. (2018). Peer mentoring in entrepreneurship education: Towards a role typology. Education and Training, 60(9), 1026-1040. https://doi.org/10.1108/ET-08-2017-0109

Lapointe, É., \& Vandenberghe, C. (2017). Supervisory mentoring and employee affective commitment and turnover: The critical role of contextual factors. Journal of Vocational Behavior, 98, 98-107. https://doi.org/10.1016/j.jvb.2016.10.004

Lascelles, M. A. (2016). Students' and Mentors' experiences of mentoring and learning in practice during the first year of an accelerated programme leading to nursing registration. Nurse Education Today, 27(8), 667-676. Retrieved from https://ec.europa.eu/growth/industry/intellectual-property_en

Lemanski, T., Mewis, R., \& Overton, T. (2011). An Introduction to Work-Based Learning: A Physical Sciences Practice Guide. UK Physical Sciences Centre

Lunsford, L. G. (2014). Mentors, tormentors, and no mentors: Mentoring Scientists. International Journal of Mentoring and Coaching in Education, 3(20), 4-17. Retrieved from http://dx.doi.org/10.1108/IJMCE-02-2013-0007

Malaysian Qualifying Agency, and Jabatan Pembangunan Kemahiran. (2016). Code of Practice for TVET Programme Accreditation. (3539), 74.

https://doi.org/10.1017/CBO9781107415324.004

Marlina, H., Gumayesty, Y., Raviola, Warlenda, S. V., Jalinus, N., \& Rizal, F. (2019). Implementation of work based learning as an effort to increase student competence in vocational midwifery education. Proceedings of the International Conference of CELSCITECH 2019 - Social Sciences and Humanities Track, 373, 46-48. https://doi.org/10.2991/iccelst-ss-19.2019.10

McGee, M. (2017). Experiential Education : Internships \& Work-Based Learning : A Handbook for Practitioners \& Administrators. 1-68.

McGowan, M. A., \& Andrews, D. (2017). Labor market mismatch and labor productivity: Evidence from piaac data. Research in Labor Economics, 45, 199-241.

Meza Rios, M. M., Herremans, I. M., Wallace, J. E., Althouse, N., Lansdale, D., \& Preusser, M. (2018). Strengthening sustainability leadership competencies through university internships. International Journal of Sustainability in Higher Education, 19(4), 739-755. https://doi.org/10.1108/IJSHE-06-2017-0097

Ministry of Finance (2020, November). Employability for Malaysians. 
http://www1.treasury.gov.my/index.php/ms/

Ministry of Education (2018). Graduate Employability. https://www.moe.gov.my/en/tvet

Ministry of Tourism, Arts, and Culture Malaysia (2020, Jun). Tourism sector in Covid-19. http://www.motac.gov.my/en/

Mohtady, H. A., Könings, K. D., Al-Eraky, M. M., Muijtjens, A. M. M., \& Van Merriënboer, J. J. G. (2019). High enthusiasm about long lasting mentoring relationships and older mentors. BMC Medical Education, 19(1), 1-9. https://doi.org/10.1186/s12909-0191791-8

Morley, D. A. (2018). Enhancing Employability in Higher Education through Work Based Learning. In Enhancing Employability in Higher Education through Work Based Learning. https://doi.org/10.1007/978-3-319-75166-5

Moses, K. M. (2016). Improving the quality and competence of technical vocational education and training output through vocational school cooperation with industry: A case study of Uganda. AIP Conference Proceedings, 1778.

Musset, P. (2019). Improving work-based learning in schools. OECD Social, Employment and Migration Working Papers, 233(233), 1-80.

https://doi.org/https://doi.org/10.1787/918caba5-en

Nabi, G., Walmsley, A., \& Akhtar, I. (2019). Mentoring functions and entrepreneur development in the early years of university. Studies in Higher Education, 1-16. https://doi.org/10.1080/03075079.2019.1665009

Neary, M. (2000). Supporting students' learning and professional development through the process of continuous assessment and mentorship. Nurse Education Today, 20(6), 463474.

Obuobisa-Darko, T. (2020). Leaders' behaviour as a determinant of employee performance in Ghana: The mediating role of employee engagement. Public Organization Review, 20(3), 597-611.

Okolie, U. C., Nwajiuba, C. A., Binuomote, M. O., Ehiobuche, C., Igu, N. C. N., \& Ajoke, O. S. (2020). Career training with mentoring programs in higher education: Facilitating career development and employability of graduates. Education and Training, 62(3), 214-234. https://doi.org/10.1108/ET-04-2019-0071

Oliver, B. (2015). Redefining graduate employability and work-integrated learning: Proposals for effective higher education and disrupted economies. Journal of Teaching and Learning for Graduate Employability, 6(1), 56-65. https://doi.org/10.21153/jtlge2015vol6no1art573

Omar, M. K., Zahar, F. N., \& Rashid, A. M. (2020). Knowledge, skills, and attitudes as predictors in determining teachers' competency in Malaysian TVET institutions. Universal Journal of Educational Research, 8(3), 95-104.

doi: 10.13189/ujer.2020.081612

Orgambídez, A., \& Almeida, H. (2019). Supervisor support and affective organizational commitment: The mediator role of work engagement. Western Journal of Nursing Research. https://doi.org/10.1177/0193945919852426

Ótala, L., (1994). Industry-university partnership: Implementing lifelong learning'. Journal of European Industrial Training, 18(8), https://doi.org/10.1108/03090599410068033

Pang, E., Wong, M., Leung, C. H., \& Coombes, J. (2019). Competencies for fresh graduates' success at work: Perspectives of employers. Industry and Higher Education, 33(1), 5565. https://doi.org/10.1177/0950422218792333 
Prunuske, A., Houss, B. A., \& Kosobuski, A. W. (2019). Alignment of roles of near-peer mentors for medical students underrepresented in medicine with medical education competencies: A qualitative study. BMC Medical Education, 19,417. https://doi.org/10.1186/s12909-019-1854-x

Salina, D., Nurazariah, A., Noraina Mazuin, S., \& Jegatheesan, R. (2011). Enhancing university business curriculum using importance-performance approach: A case study of business management faculty of a university in Malaysia. International Journal of Educational Management, 25(6), 1-21.

Seufert, S. (2000). Work-based learning and knowledge management: An integrated concept of organizational learning. In ECIS 2000 (pp. 1413-1420). The Journal of Continuing Higher Education, 50(2), 61-61. https://doi.org/10.1080/07377363.2002.10846683

Sobiechowska, P., \& Maisch, M. (2006) Work-based learning: In search of an effective model. Educational Action Research 14(2), 267-286. Retrieved from https://eric.ed.gov/?id=EJ830903

Spencer, C. (2004). Mentoring Made Easy A Practical Guide. Employment, Equity and Diversity.

Stones, E. (1994). Assessment of a complex skill: Improving teacher education. Assessment in Education: Principles, Policy and Practice, 1(2), 235-252. https://doi.org/10.1080/0969594940010207

Stirling, A., Kerr, G., Banwell, J., MacPherson, E., \& Heron, A. (2016). A practical guide for workintegrated learning effective practices to enhance the educational quality of structured work experiences offered through colleges and universities. (April), 188. Retrieved from http://www.heqco.ca/SiteCollectionDocuments/HEQCO_WIL_Guide_ENG_ACC.pdf

Terry, D., Nguyen, H., Perkins, A. J., \& Peck, B. (2020). Supervision in Healthcare: A Critical Review of the Role, Function and Capacity for Training. Universal Journal of Public Health, 8(1), 1-14. https://doi.org/10.13189/ujph.2020.080101

Tuomikoski, A. M., Ruotsalainen, H., Mikkonen, K., \& Kääriäinen, M. (2020). Nurses' experiences of their competence at mentoring nursing students during clinical practice: A systematic review of qualitative studies. Nurse Education Today, 85(June 2019), 104258. https://doi.org/10.1016/j.nedt.2019.104258

University of British Colombia. (2004). Preceptor And Mentor Effectivenes. College of Health Discipline. Retrieved on 2 Jan 2020

http://www.healthdisciplines.ubc.ca/pm/managingprograms/ evaluating/prece ptormentoreffectiveness.htmmentoreffectiveness.

Venesa, D. (2019). Demand for TVET grads to increase. Retrieved from https://www.thestar.com.my/metro/metro-news/2019/08/28

Ward, B., Schultz, J. J., Halsey, J. N., Hoppe, I. C., Lee, E. S., \& Granick, M. S. (2020). Mentorship Through Research: A Novel Approach to Increasing Resident and Medical Student Research Competency Through an Institutional Database. Journal of Surgical Education, (973), 0-2.https://doi.org/10.1016/j.jsurg.2020.04.010

Washington, R., \& Cox, E. (2016). How an evolution view of workplace mentoring relationship helps avoid negative experiences: The developmental relationship mentoring model in action. Mentoring \& Tutoring: Partnership in Learning, 24(4), 318-340.

Winberg, C., Bramhall, M., Greenfield, D., Johnson, P., Rowlett, P., Lewis, O., Waldock, J., \& Wolff, K. (2020). Developing employability in engineering education: A systematic 
review of the literature. European Journal of Engineering Education, 45(2), 165-180. https://doi.org/10.1080/03043797.2018.1534086

Wu, X., Lyu, Y., Kwan, H. K., \& Zhai, H. (2019). The impact of mentoring quality on protégés' organization-based self-esteem and proactive behavior: The moderating role of traditionality. Human Resource Management, 58(4), 417-430.

https://doi.org/10.1002/hrm.21968

Xiong, K., Lin, W., Li, J. C., \& Wang, L. (2016). Employee trust in supervisors and affective commitment: The moderating role of authentic leadership. Psychological Reports, 118(3), 829-848. https://doi.org/10.1177/0033294116644370

Zaipah, I., Qistina, N. A., Rahmah, M. Y., Yahya, B., \& Safarin, M. N. (2014). Penilaian Pembelajaran Berasaskan Kompetensi Dalam Pendidikan Teknik Dan Vokasional. International Seminar on Technical and Vocational Education, 4-56. Retrieved from http://eprints.utm.my/id/eprint/61404/ 